\title{
Orphan muscle of elbow pain: A cite to anconeus' myofascial trigger point
}

\author{
Dirsek ağrılarının yetim kası: Anconeus'un miyofasyal tetik noktasına bir atıf
}

\section{(i) Fatih BAĞCIER, ${ }^{1}$ (D) Ozan Volkan YURDAKUL, ${ }^{2}$ (D Erkan ÖZDURAN³}

To the Editor,

Myofascial pain syndrome is a common condition in musculoskeletal pathologies, and it can cause pain in the elbow area. ${ }^{[1]}$ The anconeus muscle is one of the muscles localized in the elbow area and research suggests that it may play a role in elbow pain. ${ }^{[2]}$ Miyofascial trigger point (MTrP) of the anconeus muscle can cause referred pain in the lateral epicondyle region (Fig. 1a). Studies on the treatment of lateral epicondylitis show that the anconeus muscle is ignored. David G Simons, one of the people who brought the concepts of MTrP and dry needling treatment to the literature, suggested that the anconeus muscle should be evaluated and treated in the treatment of lateral epicondylitis. ${ }^{[1]}$

The message of this article; dry needling therapy can be applied in patients diagonosed chronic lateral epicondylitis with MTrP detected in the anconeus muscle. Since it is a superficial muscle, $25 \times 13$ $\mathrm{mm}$ sterile acupuncture needle will be sufficient. The patient's elbow should be positioned at $45^{\circ}$ flexion in the supine position. To localize the muscle, the olecranon, lateral epicondyle and the posterior, superior region of the ulna (approximately 2 $\mathrm{cm}$ distal from the olecranon) are marked, and an

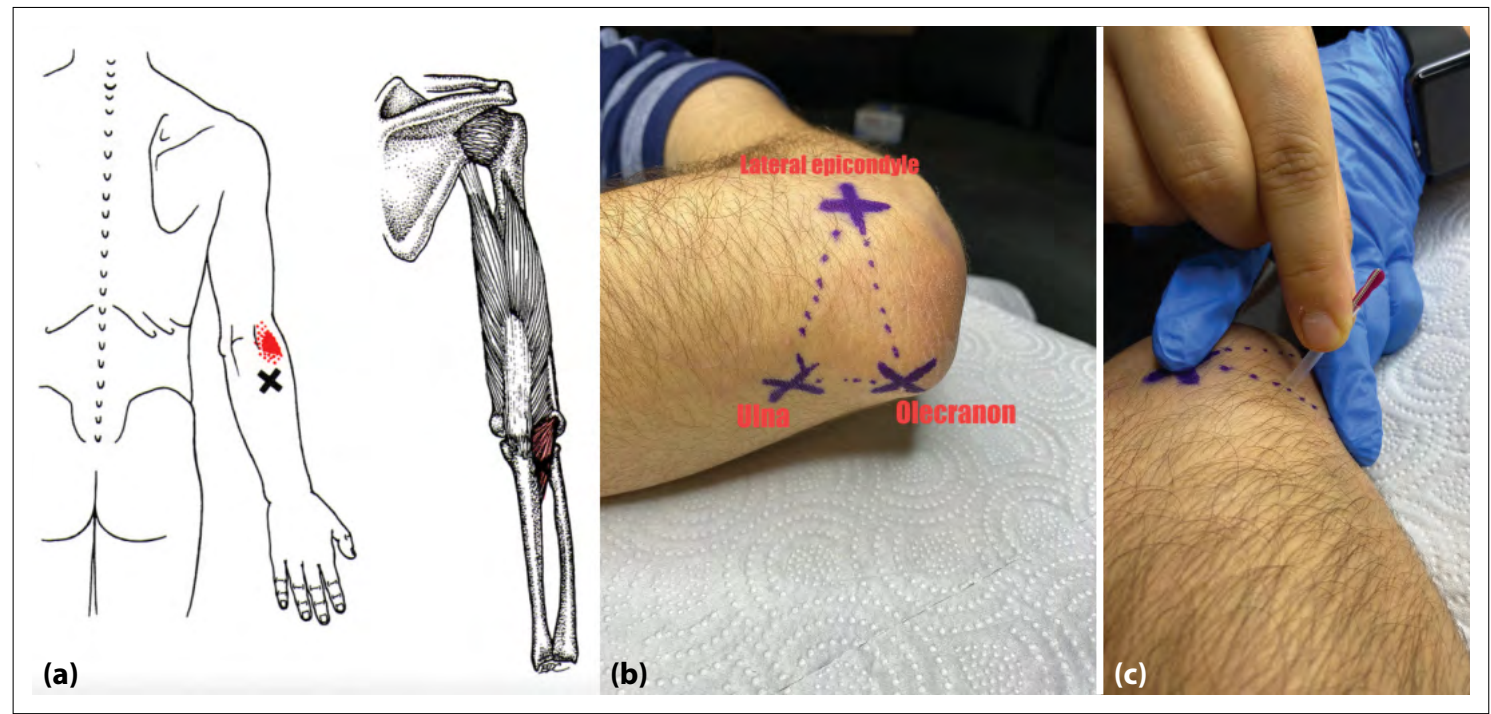

Figure 1. (a) Referred pain area of anconeus muscles trigger point (b) triangle area where the anconeus muscle is localized, (c) dry needling technique with flat palpation and perpendicular application.

\footnotetext{
'Departmant of Physical Medicine and Rehabilitation, Biruni University Faculty of Medicine, İstanbul, Turkey ${ }^{2}$ Departmant of Physical Medicine and Rehabilitation, Bezmialem Vakıf University Faculty of Medicine, İstanbul, Turkey ${ }^{3}$ Department of Physical Medicine and Rehabilitation, Haseki Training and Research Hospital, İstanbul, Turkey Submitted: 19.07.2020 Accepted after revision: 10.01.2021 Available online date: 12.01.2021

Correspondence: Dr. Fatih Bağcıer. Biruni Üniversitesi Tıp Fakültesi Hastanesi, Fiziksel Tıp ve Rehabilitasyon Anabilimdalı, İstanbul, Turkey. Phone: +90 - 544 - 2429042 e-mail: bagcier_42@hotmail.com

C) 2022 Turkish Society of Algology
} 
anatomical triangular area is formed (Fig. 1b). Treatment is comfortable in this area as it is quite safe in terms of neurovascular structures. The needle is perpendicularly penetrated the skin by flat palpation method (Fig. 1c). The needle should be navigated intramuscularly until the twitch response is obtained. Although there is no consensus on how often and how many sessions of dry needling therapy in the literature, we recommend three sessions once a week for patient compliance. ${ }^{[3]}$

\section{References}

1. Simons DG,Travell J, Simons LS. Myofascial pain and dysfunction: The trigger point manual: Volume 1. Philadelphia: Lippincott Willams \& Wilkins; 1999.

2. Miguel-Andres I, Alonso-Rasgado T, Walmsley A, Watts AC. Effect of anconeus muscle blocking on elbow kinematics: Electromyographic, inertial sensors and finite element study. Ann Biomed Eng 2017;45(3):775-88. [CrossRef]

3. Bağcıer F, Tufanoğlu FH. A new treatment modality in piriformis syndrome: Ultrasound guided dry needling treatment. Agri 2020;32(3):175-6. [CrossRef] 